\title{
The benefit attributes of the Indonesian National Standard (SNI) product
}

\author{
Muhammad Rosiawan ${ }^{1, *}$, Moses Laksono Singgih ${ }^{2}$, and Erwin Widodo ${ }^{2}$ \\ ${ }^{1}$ Department of Industrial Engineering, Universitas Surabaya, J1. Raya Kalirungkut, Surabaya, \\ Indonesia \\ ${ }^{2}$ Department of Industrial Engineering, Institut Teknologi Sepuluh Nopember, Jl. Arif Rahman \\ Hakim, Surabaya, Indonesia
}

\begin{abstract}
This research aims to measure the benefit of the Indonesian National Standard (SNI) product not only came from the company perceptions but also came from the government, academician, and consumer perceptions in Surabaya. The empirical study result showed that all of the respondents had a positive perception on the SNI product. They stated agreement that the SNI product had benefit on the attributes: quality guarantee of product, safe to use, a fair prices, quality of raw materials, and efficiency. Those attributes support the enhancement of company's competitiveness. However, most of the respondents of companies and consumers state did not know about the quality guarantee of the SNI product. The results were contradictory, the respondents who came from the companies knew more about quality guarantee of the SNI product compared to the other respondents. Furthermore, the respondents of academicians, consumers, and particularly companies state that they did not know about the easiness of the SNI certification process and the government provide an incentive for the registration fee of the SNI certification. This ignorance will impact on the perceptions that process of the SNI certification was complicated and costly. Besides, it showed that the government was less to conduct socialization for the certification program compared to socialization for the standard program. Keywords: Attributes of SNI product, Certification, Competitiveness, Respondent's perceptions
\end{abstract}

\section{Background}

A company that implements a management system standard intended to provide information (such as production efficiency, the quality of raw materials, quality product, and safety for use) to companies and customers that the resulting product comes from a controlled management system and always performs continuously improvement [1]. Unfortunately, this kind of information is often unknown to other stakeholders and become only internal information of the company. Therefore, standard and certification implementation programs in company help to disclosure of information about the hidden attributes to suppliers, customers, and other stakeholders.

\footnotetext{
${ }^{*}$ Corresponding author: mrosiawan@staff.ubaya.ac.id
} 
Most of the empirical study discusses the benefits attributes of the ISO/SNI standards mainly on the operational and financial company's performance. The primary data collected from filling of questionnaires by respondents and the secondary data obtained from the public data. The research findings showed:

a) The company got less benefited if the certification is the customer demands only [2]. But the company which has ISO 9001 certificate (caused by internal motives) to get positive benefits on operational and financial performance [3],

b) Companies benefit from operational and financial performance. Kinds of operational performance are improvements in product and service quality (Psomas \& Pantouvakis, 2015), company efficiency [4], to provide product safety, employee safety and health as well as the environment [5], improvements in the relationship between process management \& quality improvement, process management \& quality support tools [6], improved manufacturing parameters [7], technology management, participation in quality improvement programs and quality control techniques [8]. While kinds of the financial performance are increased sales revenue and return on asset [9]. But the benefits of this financial performance depend on the seriousness of the company in implementing the standards [10],

c) The SNI products strengthen the domestic market and competitiveness of the export products [11-12]

Other activities in line with standardization are conformity assessment as a statement that products, processes, systems, persons or institutions have met certain requirements, which may include testing, inspection, certification and accreditation activities [13]. Benefits of certification by credible third parties include a) reducing the frequency of product failures in the market [14], b) reducing asymmetric information between sellers and buyers about product quality [15], and c) enhancing quality and image of the company [16]. Furthermore, an empirical study in Hong Kong shows that $75 \%$ of companies surveyed stated that the cost of certification is inexpensive when compared to the benefits obtained $[2]$.

From those studies, most of the research object was the companies. While the object of research involving consumers, academicians and government was still limited, such as the study of [5] which discussed the perception of the consumers in four cities in Indonesia (Denpasar, Banjarmasin, Mataram and Manado) as respondents related to attributes of the SNI products such as product safety, safety, and health as well as environmental sustainability. Respondents of study to review of the SNI role include producers and exporters, government agencies, and employers' associations in production centers and export locations in five regions in Indonesia (Jakarta, Jawa Barat, Jawa Timur, Sumatera Utara, and Banten) [11]. Furthermore, respondents of the study of public perception on the SNI product consist of academics, companies, consumers, and government in ten big cities - Indonesia (Medan, Riau, Jakarta, Bandung, Yogyakarta, Surabaya, Samarinda, Makassar, Manado and Bali) [12]. Although the research has addressed several attributes of product SNI from the perceptions of various respondents, these studies were still partial. These studies did not address other attributes of SNI products and then arrange these attributes in a structured way to form an image of SNI product.

Therefore, this paper discusses about the respondents perception on attributes of SNI product such as raw material quality, efficiency of process, quality of product, safe to use, a fair price, product or company competitiveness, easiness of certification process, and incentives for registration fee of SNI certification. In addition, the study analyze the relationship between type of occupation with attributes of the SNI product and certification.

In order to extent those research, this paper discusses the perceptions of respondents (consumers, academicians, companies, and government agencies) on the benefit attributes 
of the SNI product. The attributes that exist in the SNI product for the design of the questionnaire are structured as follows (Figure 1.)

\begin{tabular}{|l|l|l|}
\hline Attribute for Input & Attribute for Process & \multicolumn{1}{c|}{ Attributes for Output } \\
$\begin{array}{l}\text { Quality of raw } \\
\text { material }\end{array} \longrightarrow \begin{array}{l}\text { The company } \\
\text { efficiency }\end{array} \rightarrow \begin{array}{l}\text { Quality and safety of } \\
\text { products }\end{array} \rightarrow$ Price of products \\
Competitiveness
\end{tabular}

Figure 1. Relationship between each attributes of the SNI product

Figure 1 shows that the quality of raw material has relationship with the company efficiency such as efficiency of production process. The company efficiency has relationship with quality and safety of the product. Furthermore, the fair price-high quality has relationship with the company or product competitiveness. Therefore, design of questionnaire based on relationships between these attributes in order to measure respondents' perceptions of the benefit attributes of standard (SNI) implementation.

The paper structured as follows. Firstly, the background chapter that discusses the implementation of standards and its impact. Secondly, explains the empirical research method used. Thirdly, discusses the key findings. And lastly, the conclusion, limitation and opportunities for next research.

\section{Methodology}

\subsection{Selection criteria of respondents}

Four hundred respondents in Surabaya is divided into four groups with a sample proportion: $30 \%$ for consumers, $30 \%$ for companies, $20 \%$ for academicians, and $20 \%$ for government agencies. Respondents were randomly selected and have knowledge of SNI and certification.

\subsection{Design of Questionnaire}

The questionnaire was designed to follow the attributes in Figure 1. Respondents were asked to show their agreement for each question on a four-point scale where 1 (Strongly disagree), 2 (Disagree), 3 (Agree), and 4 (Strongly agree). If the respondents did not know about the questions, then respondents are able choose the answer 0 (I do not know). In addition, the questionnaire also asked respondents regarding their perceptions of the certification process and incentives for the registration fee of certification. Table 1 shows the profile of respondents.

Table 1. Type of occupation of respondents

\begin{tabular}{|l|l|c|c|}
\hline Field of occupation & \multicolumn{1}{|c|}{ Type of occupation } & Frequency & Percent \\
\hline \multirow{2}{*}{$\begin{array}{l}\text { Government } \\
\text { Agencies }\end{array}$} & Army/Policeman & 18 & 4.5 \\
\cline { 2 - 4 } & Staff government & 61 & 15.3 \\
\hline \multirow{2}{*}{ Academicians } & Lecturer & 24 & 6.0 \\
\cline { 2 - 4 } & Teacher & 59 & 14.8 \\
\cline { 2 - 4 } & SME Employee & 38 & 9.5 \\
\cline { 2 - 4 } & SME owner & 40 & 10.0 \\
\cline { 2 - 4 } & State-owned enterprises staff & 47 & 11.8 \\
\hline Consumers & $\begin{array}{l}\text { Housewife, medical doctor/dentist, sales, staff in } \\
\text { church office, entrepreneur, lawyer, cleaning service }\end{array}$ & 113 & 28.3 \\
\hline
\end{tabular}




\section{Key Findings and Discussion}

From Table 2, approximately $70 \%$ of the respondents agree and strongly agree for attributes of the SNI product are high quality, safe to use, fair price, quality guaranteed of raw materials, improve efficiency and competitiveness. However, the perception of respondents who agree and strongly agree tends to decrease (about 50\%) for attributes about easiness of the certification process and the government provided an incentive for registration fee of SNI certification. Most of the respondents did not know the attributes about the certification.

Table 2. Perceptions of Respondents on Benefit Attributes of SNI product

\begin{tabular}{|l|l|c|c|c|c|c|}
\hline \multicolumn{2}{|c|}{ Attributes } & \multicolumn{5}{c|}{ Percent } \\
\cline { 3 - 7 } & & $\mathbf{0}$ & $\mathbf{1}$ & $\mathbf{2}$ & $\mathbf{3}$ & $\mathbf{4}$ \\
\hline a. & Quality guarantee of raw materials & 25.8 & 0.0 & 2.3 & 56.0 & 16.0 \\
\hline b. & Improves the company efficiency & 11.8 & 0.0 & 4.3 & 71.3 & 12.8 \\
\hline c. & Quality guarantee of product & 11.3 & 0.3 & 9.0 & 62.0 & 17.5 \\
\hline d. & Safe to use & 10.8 & 0.0 & 5.5 & 64.8 & 19.0 \\
\hline e. & Have a fair price & 18.6 & 1.0 & 10.0 & 59.0 & 11.5 \\
\hline f. & Easiness of certification process & 28.5 & 5.8 & 13.3 & 41.5 & 11.0 \\
\hline g. & An incentive for registration fee of the SNI certification & 32.0 & 0.8 & 14.5 & 43.5 & 9.3 \\
\hline h. & Improves product and company competitiveness & 17.3 & 0.5 & 4.3 & 65.0 & 13.0 \\
\hline
\end{tabular}

The result dependency relationship between types of occupation with attributes of SNI product used Pearson Chi-Square Test (Table 3). Table 3 shows that there is dependency relationship (whereas the value of Sig. (2-sided) is less than 0.05 ) between the types of occupation with the perceptions for: a) quality guaranteed of the SNI product, b) easiness of the SNI certification process, and c) the government provided an incentive for registration fee of the SNI certification.

Table 3. Result of dependency test (Pearson Chi-Square Test)

\begin{tabular}{|l|l|c|}
\hline \multicolumn{2}{|c|}{ Attributes } & Type of occupation \\
\hline a. & Quality guarantee of raw materials & 0.416 \\
\hline b. & Improves the company efficiency & 0.908 \\
\hline c. & Quality guarantee of product & $0.005^{*}$ \\
\hline d. & Safe to use & 0.204 \\
\hline e. & Have a fair price & 0.146 \\
\hline f. & Easiness of certification process & $0.022^{*}$ \\
\hline g. & An incentive for registration fee of the SNI certification & $0.002^{*}$ \\
\hline h. & Improves product and company competitiveness & 0.279 \\
\hline
\end{tabular}

${ }^{*}$ Statistically significant when the value of Sig. (2-sided) is less than 0.05

Furthermore, Table 4 is used cross-tabulation analysis to determine the control variables (types of occupation) which contributes to its dependency relationships. Of Table 4 shows that the respondents working in the company have higher percentage about ignorance of quality guarantee of the SNI product compared to the respondents working in the government agencies or as an academician. The result is contradictory because the respondents who working in the company are directly involved in the production process and quality of product and they should know more about the quality product compared to other respondents. Furthermore, many of respondents (academician, consumers, companies 
and government agencies) state that they also did not know about the certification attributes (e.g. the easiness of the SNI certification process and an incentive for the registration fee of the SNI certification) compared to the SNI product attributes. The result state that the socialization of the certification program is rare.

Table 4. Cross-tabulation between the type of occupation and attributes of the SNI product

\begin{tabular}{|c|c|c|c|c|c|}
\hline \multirow[t]{2}{*}{ Attributes } & \multirow{2}{*}{$\begin{array}{l}\text { Level of } \\
\text { perception }\end{array}$} & \multicolumn{4}{|c|}{ Types of occupation (Percentages) } \\
\hline & & $\begin{array}{c}\text { Government } \\
\text { Agencies }\end{array}$ & Academicians & Companies & Consumers \\
\hline \multirow{5}{*}{$\begin{array}{l}\text { Quality guarantee of } \\
\text { product }\end{array}$} & 0 & 0.5 & 0.0 & 4.3 & 4.0 \\
\hline & 1 & 0.0 & 2.5 & 0.3 & 0.0 \\
\hline & 2 & 3.0 & 2.5 & 4.3 & 2.0 \\
\hline & 3 & 16.0 & 13.3 & 16.0 & 16.8 \\
\hline & 4 & 3.0 & 2.5 & 6.5 & 5.5 \\
\hline \multirow{5}{*}{$\begin{array}{l}\text { Easiness of } \\
\text { certification process }\end{array}$} & 0 & 3.0 & 6.0 & 9.5 & 10.0 \\
\hline & 1 & 0.5 & 1.3 & 2.8 & 1.3 \\
\hline & 2 & 3.0 & 3.8 & 2.5 & 4.0 \\
\hline & 3 & 11.5 & 8.0 & 12.5 & 9.5 \\
\hline & 4 & 1.8 & 1.8 & 4.0 & 3.5 \\
\hline \multirow{5}{*}{$\begin{array}{l}\text { Easiness of } \\
\text { certification process }\end{array}$} & 0 & 3.0 & 7.8 & 10.3 & 11.0 \\
\hline & 1 & 0.0 & 0.0 & 0.8 & 0.0 \\
\hline & 2 & 3.3 & 3.5 & 4.5 & 3.3 \\
\hline & 3 & 12.5 & 7.8 & 11.5 & 11.8 \\
\hline & 4 & 1.0 & 1.8 & 4.3 & 2.3 \\
\hline
\end{tabular}

\section{Conclusion}

The results show that the products certified by SNI already have attributes such as quality of raw material, efficiency of the company, product quality, safety in use, and fair price. Most of respondents agreed that the SNI product is able increase the competitiveness.

The research findings that different from previous studies because of the asymmetric information for the SNI certification program. Most of the staffs and owners of company who did not know the information about the certification process and an incentive for registration fee SNI certification provided by the government. This ignorance may cause the SNI certification process is complicated and costly. While the companies strongly agreed that the application of standards and certifications improve the company efficiency. It should be the concern of government agencies related to standards and certification to increase the frequency socialization about certification programs to companies. The frequency socialization is able to maintain the positive perceptions of the implementation of standards and the certification programs.

This research is still limited to respondents in Surabaya. Therefore, it is necessary to expand the scope of its respondents in Indonesia to obtain more general results. Furthermore, the future research is able to measure the impact of standards and certifications on the company performance through using the company's operational data.

\section{Acknowledgments}

The research was funded by Deputy of Information and Socialization of Standardization National Standardization Agency for the data collection. Besides, the research conduct by students and Head of Quality Performance Management Laboratory- Department of 
Industrial Engineering, University of Surabaya are as surveyors and a coordinator of survey.

\section{References}

1. E. L. Psomas and A. Pantouvakis., TQM J., 27, 5, 519-531 (2015).

2. H. K. N. Leung, K. C. C. Chan, and T. Y. Lee, Int. J. Qual. Reliab. Manag., 16, 7, 675-691 (1999).

3. P. Sampaio, P. Saraiva, and A. G. Rodrigues, Int. J. Qual. Reliab. Manag., 28, 9, 929950 (2011).

4. D. Tzelepis, K. Tsekouras, D. Skuras, and E. Dimara, Int. J. Oper. Prod. Manag., 26, 10, 1146-1165 (2006).

5. F. Isharyadi, A. Wibowo, and Suminto, J. Stand., 19, 1, 71-78 (2017).

6. E. L. Psomas, C. V. Fotopoulos, and D. P. Kafetzopoulos, Bus. Process Manag. J., 17, 3, 437-460 (2011).

7. T. Koc, J. Mater. Process. Technol., 186, 207-213 (2007).

8. A. Gupta, Ind. Manag. Data Syst., 100, 9, 451-455 (2000).

9. F. Starke, R. V. Eunni, N. M. M. D. Fouto, and C. F. de Angelo, Manag. Res. Rev., 35, 10, 974-997 (2012).

10. P. Sampaio, P. Saraiva, and A. Monteiro, Int. J. Qual. Reliab. Manag., 29, 8, 891-914, (2012).

11. BPPKP-Kemendag, "Kajian Peranan SNI Untuk Penguatan Pasar Dalam Negeri dan Daya Saing Produk Ekspor Pusat Kebijakan Perdagangan Dalam Negeri Badan Pengkajian dan Pengembangan Kebijakan Perdagangan Kementerian Perdagangan Republik Indonesia," 2015.

12. Kedeputian-IPS-BSN, "Laporan Akuntabilitas Kinerja Instansi Pemerintah Kedeputian Informasi dan Pemasyarakatan Standardisasi Tahun Anggaran 2016," 2017.

13. M. Eto, M. Song, J. Henry, H. Lee, H.-D. Yang, and H. Lee, Standardization: Fundamentals, Impact and Business Strategy. APEC Secretariat, 2010.

14. J. A. Clougherty and M. Grajek, Int. J. Ind. Organ., 36, 70-82 (2014).

15. I. Vertinsky and D. Zhou, Int. Mark. Rev., 17, 3, 231-252 (2000).

16. B. Buehler and F. Schuett, Eur. Econ. Rev., 70, 493-511 (2014). 